\title{
Hubungan Pendidikan Kedisiplinan Ibu dengan Kebersihan Toilet Anak Usia 4-6 Tahun
}

\author{
Leny Marlina ${ }^{1}$, Fuaddilah Ali Sofyan ${ }^{1 凶}$, Aida Imtihana ${ }^{1}$, Alda Monika ${ }^{1}$ \\ Pendidikan Islam Anak Usia Dini, Universitas Islam Negeri Raden Fatah Palembang, \\ Indonesia(1) \\ DOI: $10.31004 /$ obsesi.v6i3.2014
}

\begin{abstract}
Abstrak
Permasalahan yang sering kali terjadi di dalam lingkungan sekolah ialah toilet yang berbau tidak sedap karena anak buang air kecil di lantai toilet dan tidak menyiram bekas buang air besar dan buang air kecil. Anak juga mengabaikan kebersihan diri dengan tidak membersihkan alat kelamin setelah buang air kecil dan masih membutuhkan bantuan untuk membersihkan duburnya setelah buang air besar. Penelitian ini bertujuan untuk mengetahui apakah terdapat hubungan pendidikan kedisiplinan ibu dengan kebersihan toilet anak usia 45 tahun di PAUD Nurul Qomar Kelurahan Mulia Agung Kecamatan Banyuasin III. Menggunakan metode kuantitatif dengan pendekatan korelasional. Subjek penelitian ini ialah peserta didik di PAUD Nurul Qomar yang berusia 4-6 tahun berjumlah 15 orang dengan menggunakan total sampling dengan menggunakan teknik pengumpulan data angket, observasi, dan dokumentasi. Adapun analisis data yang digunakan ialah uji normalitas, uji linieritas, dan uji korelasi dengan menggunakan uji korelasi product moment. Hasil penelitian menunjukkan terdapat hubungan antara pendidikan kedisiplinan ibu dengan kebersihan toilet anak usia 4-6 tahun.
\end{abstract}

Kata kunci : kedisiplinan; kebersihan toilet di sekolah; anak usia dini

\begin{abstract}
The problem that often occours in the school enviroment is a toilet that smells bad because children arinate on teh toilet floor and do not flush the former defecation and urinate. In addition, students who ignore personal hygiene by not cleaning their genitals after urinating and need help to clean their rectum after defecating. The study auns to determine the relationship between maternal discipline education and toilet hygiene for children agaed 4-6 years at Nurul Qomar early childhood education Mulia Agung Village, Banyuasin III District. This study uses a quantitative method with a correlational approach. The subjects in this study were 15 students in PAUD Nurul Qomar aged 4-6 years, using questionnaires, observation, and documentation data collection techniques. The data analysis used is the normality test, linearity test, and correlation test using the product moment correlation test with the results obtained from the correlation coefficient $r_{\text {count }}(0.779)>r_{\text {table }}(0.524)$, so that $\mathrm{H}_{0}$ is rejected and $\mathrm{H}_{\mathrm{a}}$ is accepted, meaning that there is a relationship between maternal discipline education and toilet hygiene for children agaed 4-6 years.
\end{abstract}

Keywords: discipline; toilet hygiene; early childhood.

Copyright (c) 2022 Leny Marlina, et al.

$\triangle$ Corresponding author:

Email Address : monikaalda24@gmail.com (Palembang, Indonesia)

Received 26 September 2021, Accepted 29 December 2021, Published 16 January 2022 


\section{PENDAHULUAN}

Pendidikan merupakan suatu proses penanaman dan pengembangan pengetahuan mengenai hidup dengan mengajarkan untuk membedakan sikap dan perilaku yang benar dan yang salah serta yang baik dan buruk sehingga tingkah laku tersebut dapat diterima di masyarakat (Zaim Elmubarok, 2009). Pada jenjang Pendidikan Anak Usia Dini (PAUD) pendidikan yang dilakukan lebih menanamkan kepada pendidikan karakter dibandingkan pendidikan membaca, menulis, dan berhitung. Menurut Ratna Megawangi yang merupakan pencetus pendidikan karakter di Indonesia menyusun karakter yang diajarkan kepada anak usia dini menjadi 9 pilar yaitu : cinta tuhan, kebenaran, tanggungjawab, kedisiplinan, kemandirian, amanah, hormat, santun, kasih sayang, kepeduluan, dan kerjasama (Sujiono, 2012). Indonesia Heritage Foundation (IHF) dalam Haryati (2013) menyusun 9 pilar pendidikan karakter perlu ditanamkan sejak usia dini agar anak tumbuh dan berkembang menjadi pribadi yang sesuai dengan standar yang ada di dalam masyarakat seperti karakter tanggungjawab, kemandirian, amanah, hingga disiplin untuk mengikuti aturan.

Affrida dalam Dikdik Pramono dan Anni Risnawati (2018) menyatakan bahwa disiplin merupakan sifat yang dimiliki oleh seseorang dari hasil belajar dan latihan yang dilakukan di rumah maupun di sekolah. Tujuan disiplin dalam jangka pendek ialah untuk mengontrol perilaku yang baik dan buruk pada anak dan dalam panjang disiplin bertujuan untuk menumbuhkan sikap patuh terhadap peraturan yang ada dan tubuh sikap bertanggungjawab. Menurut E. B. Hurlock (1987) terdapat tiga cara untuk menanamkan kedisiplinan pada anak yaitu : a) disiplin otoriter, yaitu cara menanamkan kedisiplinan dengan menetapkan peraturan-peraturan yang keras dan memaksakan kehendak orang tua dan anak harus tunduk dengan peraturan tersebut; b) disipin permisif, yaitu cara menanamkan kedisiplinan dengan menggunakan cara disiplin yang lunak atau tidak membimbing anak dengan pola perilaku yang disetujui oleh masyarakat; c) disiplin demokratis, yaitu cara menanamkan kedisiplinan dengan cara memberikan penjelasan, bimbingan, penalaran dan diskusi kepada anak agar anak mengerti dari tujuan perilaku yang dijarkan oleh ibunya. Spock berpendapat bahwa hanya terdapat dua cara untuk menanakan kedisiplinan pada anak yaitu disiplin dengan cara disiplin otoriter dan mengahasilkan anak yang baik dan disiplin dengan cara permisif dan menghasilkan anak yang menaja, kedua cara tersebut tidak berhasil baik (Hurlock, 1999). Yang bertugas menanamkan disiplin di rumah ialah orang tua khususnya ibu karena ibu merupakan sosok yang paling banyak menghabiskan waktu bersama anak dan sekolah pertama bagi anak, terdapat beberapa faktor yang mempengaruhi ibu dalam menanamkan kedisiplinan pada anak yaitu : a) kesamaan dengan kedisiplinan yang digunakan oleh orang tua terdahulu sehingga seperti tradisi yang patut dicontoh secara turun temurun; b) usia orang tua, biasanya orang tua yang lebih mudah cenderung menggunakan cara disiplin demokratis; c) riwayat pendidikan dan status ekonomi, dan d) usia anak dimana jenis disiplin otoriter lebih umum digunakan kepada anak usia dini karena ibu beranggapan bahwa anak usia dini belum mengerti penjelasan menggunakan katakata sehingga perlu pemusatan perhatian dengan cara yang tegas (Hurlock, 1999).

Menurut Peraturan Menteri Pendidikan dan Kebudayaan Republik Indonesia Nomor 137 Tahun 2014 tentang Standar Nasional Pendidikan Anak Usia Dini dengan Standar Tingkat Percapaian Pekembangan Anak (STPPA) menjelaskan bahwa anak usia 4-6 tahun memiliki koordinasi gerak yang baik seperti dapat menjaga keseimbangan, berlari, melompat, dan berjalan (Fisik-Motorik), dapat membaca doa sehari-hari, dapat menjalankan ibadah, menjaga kebersihan diri dan lingkungan (Agama dan Moral), serta anak dapat mengungkapan keinginannya dan mengutarakan pendapat (Bahasa) (Permendikbud, 2014). Berdasarkan hasil survei Kesehatan Rumah Tangga Nasional pada tahun 2013 diperkirakan jumlah anak mencapai $30 \%$ atau 250 juta jiwa dan 75 juta anak yang masih kesulitan untuk mengontrol buang air besar dan buang air kecil (Yuliana et al., 2018) serta 46\% anak prasekolah di Indonesia yang buang air besar dan buang air kecil di sembarang tempat (Magdalena \& Melly, 2019) dari hasil penelitian tersbut anak belum bisa menjaga kebersihan toilet karena buang air 
besar dan buang air kecil tidak pada toilet atau kloset yang ada. Penelitian yang dilakukan oleh Magdalena dna Melly diperkuat oleh data UNICEF yang menunjukkan bahwa hampir 25 juta orang di Indonesia tidak menggunakan toilet saat buang air besar dan buang air kecil di sembarang tepat dibandingkan di toilet, karena hal tersebut seperempat dari anak usia dini di Indonesia menderita diare dan penyebab kematian yang besar pada anak di Indonesia (Unicef, 2019). Penelitian serupa yang dilakukan oleh Hayati (2019) bahwa etika menggunakan toilet pada anak laki-laki pada siklus I menunjukkan angka $86 \%$ menyiram toilet setelah buang air besar dan buang air kecil, dan 100\% anak perempuan menyiram bekas air besar dan buang air kecil. Pad siklus ke II menunjukkan peningkatan bahwa peserta didik laki-laki 93\% menyiram bekas buang air besar dan buang air kecil dan 100\% peserta didik permpuan menyiram bekas buang air besar dan buang air kecil maka kehadiran peneliti mmeberikan peningkatan untuk meningkatkan etika penggunaan toilet pada anak.

Dari hasil penelitian Magdalena \& Melly (2019) dan UNIECEF serta observasi yang dilakukan di PAUD Nurul Qomar terhadap 15 responden dimana terdiri atas anak laki-laki dan perempuan yang berusia 4-6 tahun terdapat permasalahan dalam penggunaan toilet ialah terdapat anak yang buang air kecil di lantai toilet, tidak menyiram bekas buang air kecil dan buang air besar, serta tidak membasuh alat kelamin setelah buang air kecil dan membutuhkan bantuan guru untuk membersihkan duburnya setelah buang air besar. Seseorang dapat menjaga kebersihan diri serta lingkungan merupakan suatu proses latihan panjang yang dilakukan sejak uisa dini oleh karena itu jika sejak dini tidak dibiasakan untuk menggunakan toilet dengan baik dan menjaga kebersihan diri serta lingkungan maka hingga dewasa kebiasaan tersebut akan tetap dilakukan hal inilah yang menyebabkan toilet yang ada di sekolah sering menimbulkan bau tidak sedap dan kotor. Proses observasi yang dilakukan oleh peneliti di PAUD Nurul Qomar bertujuan untuk melihat bagaimana cara kedisiplinan yang dilakukan oleh ibu sehingga menimbulkan permasalahan dalam menjaga kebersihan toilet seperti yang telah disebutkan. Oleh karena itu, untuk mengetahui mengapa permasalahan di atas selalu terjadi peneliti melakukan penelitian mengenai hubungan kedisiplinan ibu dengan kebersihan toilet anak usia 4-6 tahun di sekolah. Berdasarkan latar belakang yang telah dijelaskan di atas bahwa rumusan masalah pada penelitian ialah "Bagaimana pendidikan kedisiplinan yang digunakan ibu dalam mengajarkan kebesihan toilet pada anak usia 4-6 tahun di PAUD Nurul Qomar?" dan "Apakah terdapat hubungan pendidikan kedisiplinan ibu dengan kebersihan toilet pada anak usia 4-6 tahun di sekolah di PAUD Nurul Qomar?". Adapun tujuan dari penelitian ini ialah untuk mengetahui bagaimana cara kedisiplinan yang digunakan ibu dalam mengajarkan kebersihan toilet pada anak usia 4-6 tahun dan untuk mengetahui hubungan kedisiplinan ibu dengan kebersihan toilet pada anak usia 4-6 tahun di PAUD Nurul Qomar.

Manfaat penelitian ini secara khusus memberi masukan kepada orang tua khusunya ibu untuk mengajarkan anak toilet training atau latihan penggunaan toilet selama dirumah sehingga saat anak telah memasuki jenjang pendidikan anak usia dini anak dapat menjaga kebersihan diri dan lingkungan dengan cara menggunakan kloset saat BAB atau BAK, menyiram bekas BAB atau BAK, serta membersihkan alat kelaminnya setelah BAB dan BAK. Selain itu, manfaat penelitian ini bagi orang tua khususnya ibu memberi masukan kepada ibu untuk mengajarkan anak menjaga kebersihan toilet dengan benar dan membiasakan untuk BAK di kloset, menyiram bekas BAK, dan membersihkan kemaluan serta tangan sehabis BAB dan BAK agar anak disiplin untuk menjaga kebersihan diri dan lingkungan, dan memberi masukan kepada guru untuk memperhatikan dan mengingatkan kepada anak untuk menggunakan toilet sesuai fungsinya agar dapat menerapkan hidup bersih dan sehat.

Beberapa hal yang dapat dilakukan oleh orang tua agar disiplin ialah : a) pembiasaan dan latihan, dengan latihan yang dilakukan akan menumbukan kebiasaan bagi anak; b) pengamatan dan tegruan, dalam menanamkan kedisiplinan pada anak diperlukan pengamatan agar saat anak melakukan hal yang berlawanan dari apa yang dijarkan dapat ditegur; dan c) pujian dan hukuman, dalam mengajarkan anak kedisiplinan dieprlukan pujian 
agar anak merasa perbuatan yang dilakukannya dihargai dan hukuman diberikan dengan tujuan pendidikan bukan memeberikan efek jera dan membuat anak takut (Maskuri, 2018). Faktor yang mempengaruhi kedisiplinan anak yang paling besar ialah faktor keluarga karena keluarga yang paling dekat dengan anak dan lingkungan yang pertama kali mengajarkan disiplin pada anak, selain itu lingkungan pertemanan dan lingkungan sekolah juga dapat mempengaruhi kedisiplinan anak jika anak yang diajarkan disiplin yang baik tetapi bertmean dengan dengan teman yang tidak memiliki sikap kedisiplinan maka anak akan terengaruh untuk tidak disiplin, oleh karena itu dalam menanamkan kedisiplinan kepada anak diperlukungan dukungan keluarga dan lingkungan sekitar agar tujuan dari penanaman kedisiplinan anak berjalan sesuai dengan tujuan yang diingkan. Berdasarkan teori perkembangan psikoanalisis Sigmund Freud (dalam Wong 2008) menyatakan bahwa anak usia 4-6 termasuk ke dalam masa phalik dan latensinya dimana pada usia tersebut anak dapat membedakan jenis kelamin dan dapat buang air bsar dan buang air kecil di tempatnya dan lingkungan memberikan pengaruh yang besar.

Sesuai dengan Keputusan Menteri Kesehatan Republik Indonesia Nomor 1429/MENKES/SK/XII/2006 tentang Pedoman Penyelenggaraan Kesehatan Lingkungan Sekolah pada point ke tiga mengenai tata laksana yang berisi bahwa : a) toilet dalam keadaan bersih dan tidak berbau; b) terdapat slogan atau peringatan untuk menjaga kebersihan; c) pengurasan bak penampung air dilakukan paling lama 1 kali seminggu; d) bila bak air tidak digunakan dalam jangka waktu lama (misalnya pada saat musim libur panjang), maka bak harus dikosongkan; d) menggunakan diinfektan untuk membersihkan lantai dan kloset serta urinoir dan; e) menyediakan sabun cuci tangan. Penggunaan toilet di sekolah akan lebih baik jika memperhatikan (Kemenkes RI, 2006).

Dari hasil penelitian terdahulu dan data UNICEF memberikan mesukan kepada peneliti untuk melakukan penelitian mengenai pendidikan kedisiplinan ibu terhadap kebersihan toilet anak usia 4-6 tahun dimana terdapat 46\% anak usia prasekolah di Indonesia buang air besar dan buang air kecil di sekolah dan terdapat seperempat anak usia dini di Indonesia menderita diare karena lingkungan yang tidak bersih yang disebabkan proses buang air besar dan buang air kecil sembarangan, melihat data tersbeut peneliti tertarik untuk melakukan penelitian terhadap bagaimana cara ibu dalam menanakan kedisiplinan dalam menjaga kebersihan toilet anak usia 4-6 tahun di PAUD Nurul Qomar. Permasalah yang terdapat di PAUD Nurul Qomar pada anak usia 4-6 tahun bahwa terdapat anak yang buang air kecil di lantai toilet bukan pada kloset yang telah disediakan, terdapat anak yang tidak menyiram bekas buang air besar dan buang air kecil, dan terdapat anak yang tidak membersihkan alat kelamin setelah buang air kecil dan tidak membasuh duburnya setelah buang air besar.

\section{METODOLOGI}

Penelitian ini dilaksanakan di PAUD Nurul Qomar Kelurahan Mulia Agung Kecamatan Banyuasin III. Penelitian ini menggunakan jenis penelitian kuantitatif dengan pendekatan korelasional karena pendekatan kuantitatif merupakan jenis penelitian yang spesifikasinya dinyatakan secara sistematis, terencana, dan terstruktur secara jelas dan menggunakan angka sebagai penunjang data (Sodik, 2015) dan mempresentasikan derajat hubungan antara variabel-variabel penelitian (Ismail, 2018). Sampel penelitian ini berjumlah 15 orang dengan menggunakan teknik total sampling karena sampel yang di ambil merupakan seluruh dari jumlah populasi dan kurang dari 30 orang. Pemilihan jumlah sampel diambil berdasarkan usia anak yaitu usia 4-6 tahun dalam hal ini seluruh peserta didik di PAUD Nurul Qomar memenuhi kriteria usia tersebut dan terdiri dari anak laki-laki dan perempuan. Rekrutmen responden baik ibu maupun anak dilakukan secara sukarela tanpa ada paksaan dengan cara peneliti menjelaskan maksud dan tujuan dari penelitian ini. Teknik pengumpulan data yang digunakan pada penelitian ini ialah : angket, observasi, wawancara, dan dokumentasi. Teknik pengumpulan data dengan metode angket pada penelitian ini terdiri 
atas 30 pertanyaan namun hanya terdapat 19 pertanyaan yang valid dan digunakan sebagai alat pengumpalan data pada penelitian ini dan ditujukan kepada ibu yang memiliki anak usia 4-6 tahun di PAUD Nurul Qomar dengan alternatif jawaban yang telah disediakan yang menggunakan skala likert.

Teknik pengumpulan data dengan metode observasi dilakukan dengan jenis observasi non-partisipan, dengan metode non-partisipan objek penelitian dapat melakukan kegiatannya tanpa harus terganggu oleh kehadiran peneliti. Terdapat 3 hal yang menjadi fokus pada teknik observasi inin yaitu cara anak untuk menggunakan kloset saat buang air kecil, cara anak menjaga kebersihann lingkungan yang dilihat dari cara menyiram atau tidaknya anak setelah buang air kecil dan buang air besar, dan membersihkan atau tidaknya alat kelamin setelah buang air kecil serta memerlukan bantuan guru untuk membersihkan duburnya setelah buang air besar Pada penelitian ini terdiri atas 30 pertanyaan namun hanya terdapat 19 pertanyaan yang valid dan digunakan sebagai alat pengumpalan data dengan lembar observasi diisi langsung oleh peneliti dengan cara memberi tanda ceklist pada alternatif jawaban pada skala likert yang telah disediakan.

Adapun teknik analisis data yang digunakan untuk memperoleh hasil penelitian ialah : uji normalitas data dengan rumus kolmogrob-smirnov, uji linieritas data menggunakan rumus regresi linier sederhana, dan uji hipotesis menggunakan rumus korelasi product moment. Prosedur penelitian ini dilakukan dapat dilihat pada gambar 1.

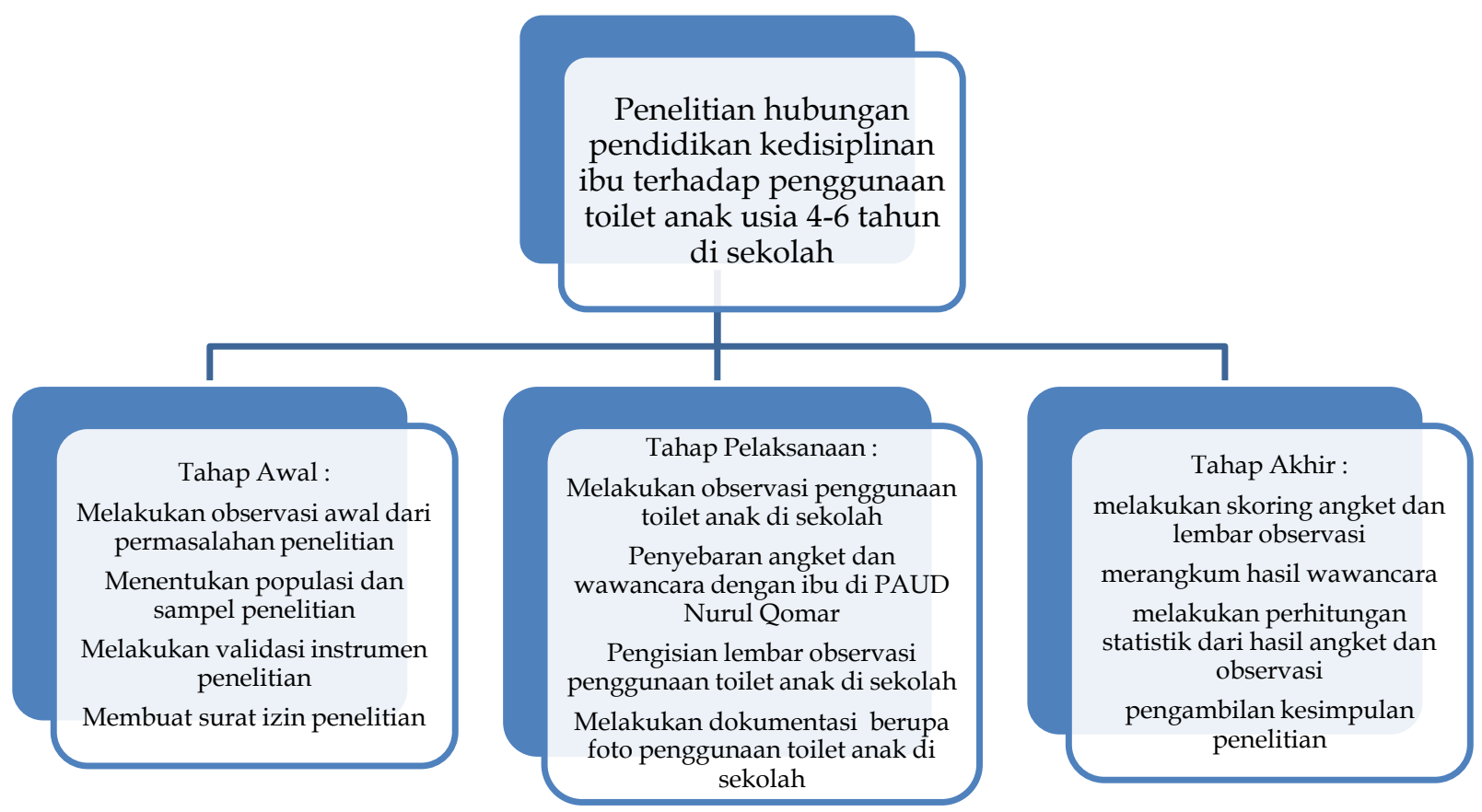

Gambar 1. Langkah-Langkah Penelitian

\section{HASIL DAN PEMBAHASAN}

Sebelum melakukan proses penelitian terlebih dahulu peneliti melakukan observasi selama 3 minggu untuk melihat cara anak dalam menjaga kebersihan toilet yang dilihat bagaimana cara anak memanfaatkan kloset untuk buang air kecil, kemampuan anak untuk menyiram bekas buang air besar dan buang air kecil, dan kemampuan anak untuk membersihkan alat kelaminnya setelah buang air kecil dan memebrsihkan dubur setelah buang air besar. Dan melakukan penyebaran angket selama 2 hari untuk memperoleh data kedisiplinaan yang digunakan oleh ibu untuk menanamkan kedisiplinan menjaga kebersihan pada anak.

Menurut E. B. Hurlock (1999) terdapat tiga cara mengajarkan kedisiplinan yang bisa digunakan oleh ibu, yaitu: a) disiplin otoriter, yaitu cara kedisiplinan dengan menggunakan 
kalimat-kalimat yang tegas dan memberikan peraturan untuk patuh terhadap aturan yang ditetapkan oleh ibu; b) disiplin permisif, yaitu cara kedisiplinan dnegan cara cara yang lunak dan membebaskan anak untuk melakukan hal yang diinginkannya; dan c) disiplin demokratis, yaitu cara kedisiplinan dengan mendisukusikan, mengarahkan, dan menjelaskan cara dan tujuan kedisiplinan yang ingin dicapai. Pada penelitian ini peneliti menggunkan tiga jenis kedisiplinan menurut Hurlock sebagai acuan untuk menyusun instrumen penelitian. Metode angket pada penelitian ini terdiri atas 19 pertanyaan sehingga diperoleh hasil sebagaimana pada tabel 1.

Tabel 1. Deskripsi Data Pendidikan Kedisiplinan Ibu

\begin{tabular}{ccc}
\hline Jenis Kedisiplinan & Frekuensi $(\mathrm{F})$ & Presentase \\
\hline Permisif & 6 & $40 \%$ \\
Otoriter & 9 & $60 \%$ \\
Demokratis & 0 & $0 \%$ \\
Jumlah & 15 & $100 \%$ \\
\hline
\end{tabular}

Berdasarkan tabel 1 dapat dilihat dari 15 responden terdapat 6 ibu (40\%) yang menggunakan jenis kedisiplinan permisif dalam mengajarkan anak untuk menggunakan toilet, terdapat 9 ibu $(60 \%)$ ibu memilih menggunakan cara otoriter untuk mengajarkan kedisiplinan anak, dan $0 \%$ atau tidak ada ibu yang menggunakan cara permisif untuk mengajarkan kedisiplinan pada anak. Untuk lebih jelas dapat dilihat diagram pada gambar 2.

\title{
Pendidikan Kedisiplinan Ibu
}

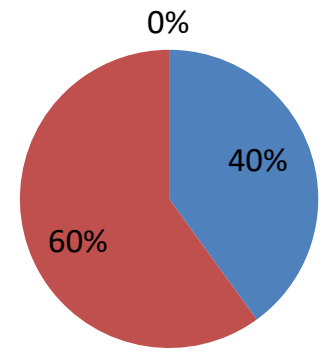

\author{
- Permisif \\ - Otoriter \\ Demokratis
}

\section{Gambar 2. Diagram Presentase Pendidikan Kedisiplinan Ibu}

Dari tabel 1 dan diagram gambar 2 diatas dapat dilihat pendidikan kedisiplinan yang paling banyak digunakan ialah dengan cara otoriter yang menunjukkan presentase $60 \%$. Seperti wawancara yang telah dilakukan oleh peneliti bahwa alasan beberapa ibu yang menggunakan jenis kedisiplinan otoriter karena beranggapan bahwa anak lebih mudah mengerti jika diajarkan dengan kalimat yang tegas dan tidak meremehkan arahan yang diberikan, seperti pendapat Hurlock (1999) yang mengatakan bahwa terdapat beberapa faktor yang mempengaruhi pendidikan kedisiplinan ibu antara lain : kesamaan dengan kedisiplinan yang digunakan oleh orang tua terdahulu sehingga seperti tradisi yang patut dicontoh secara turun temurun, usia orang tua, riwayat pendidikan dan status ekonomi keluarga pemilihan kedisiplinan otoriter ibu dapat dipengaruhi oleh kesamaan kedisiplinan yang digunakan oleh orang tuanya terdahulu yang melihat bahwa dirinya berhasil menggunakan toilet dengan benar saat diajarkan dengan cara otoriter sehingga jika anak diajarkan dengan cara yang sama akan memperoleh hasil yang sama. Terdapat $40 \%$ ibu yang mengajarkan dengan cara permisif dengan alasan kasihan anak yang masih kecil jika diajarkan dengan kalimat yang tegas dimana nantinya akan membuat ia menjadi takut dan tertekan sehingga dengan cara yang lembut anak merasa santai dengan pembelajaran menggunakan toilet yang diajarkan ibu, dan $0 \%$ atau tidak ada ibu yang mengguankan pendidikan kedisiplinan dengan cara demokratis. Dengan demikian dapat disimpulkan bahwa sebagian besar ibu yang memilki anak usia 4-6 
tahun di PAUD Nurul Qomar menggunakan cara otoriter untuk menanamkan kedisiplinan pada anak.

Pada variabel menjaga kebersihan toilet anak di sekolah peneliti menggunakan metode observasi dengan pilihan jawaban menggunakan skala likert dan terdiri atas 19 pertanyaan. Pengukuran cara menjaga kebersihan toilet anak di sekolah pada penelitian ini dikategorikan menjadi 3 yaitu anak dapat menggunakan kloset, anak dapat menyiram bekas BAB dan BAK, dan anak dapat membersihkan alat kelaminnya setelah BAB dan BAK.

Tabel 2. Deskripsi Data Pendidikan Kedisiplinan Ibu

\begin{tabular}{lcc}
\hline \multicolumn{1}{c}{ Kategori Penggunaan Toilet } & Frekuensi (F) & Presentase \\
\hline Anak BAK di lantai toilet & 3 & $20 \%$ \\
Anak belum bisa menyiram bekas BAB dan BAK & 7 & $46.6 \%$ \\
Anak belum bisa membersihkan alat kelamin setelah BAB dan BAK & 5 & $33.3 \%$ \\
\hline Jumlah & 15 & $100 \%$ \\
\hline
\end{tabular}

Berdasarkan tabel 2 dari 15 siswa di PAUD Nurul Qomar yang dijadikan sebagai objek penelitian terdapat 3 anak (20\%) yang BAK di lantai toilet artinya terdapat 12 anak yang telah bisa BAK di kloset, selain itu terdapat 7 anak (46.3\%) yang belum bisa menyiram menyiram bekas BAB dan BAK dengan 8 anak yang telah bisa menyiram bekas BAB dan BAKnya sendiri, dan terdapat 5 anak (33.3\%) yang belum bisa membersihkan alat kelaminnya setelah BAB dan BAK dengan 10 anak telah bisa membersihkan alat kelaminnya setelah BAK dan membersihkan duburnya sendiri setelah BAB tanpa bantuan guru. Untuk lebih jelas dapat dilihat pada diagram pada gambar 3.

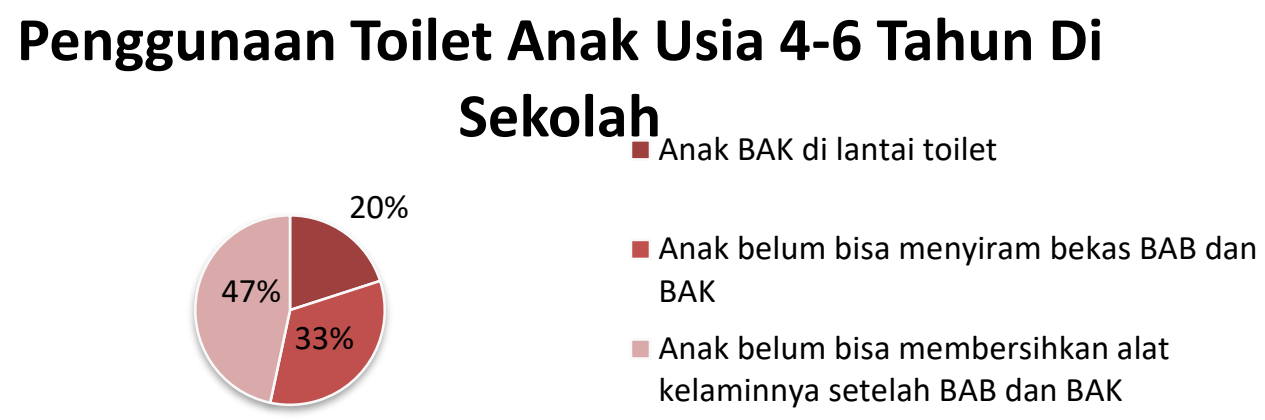

\section{Gambar 3. Diagram Penggunaan Toilet Anak Di Sekolah}

Berdasarkan hasil angket dan observasi untuk mengetahui hubungan pendidikan kedisiplinan ibu dengan kebersihan toilet anak di PAUD Nurul Qomar maka dilakukan uji normalitas dan linieritas data terlebih dahulu agar mengetahui apakah data yang diperoleh berdistribusi secara normal atau tidak serta untuk mengetahui ada tidaknya hubungan antara variabel pendidikan kedisiplinan ibu dengan penggunaan toilet anak di sekolah. Setelah melakukan uji normalitas dan linieritas data selanjutnya dilakukan pengujian hipotesis dengan menggunakan korelasi product moment dengan menggunakan SPSS versi 16.0 dengan taraf signifikasnsi 0,05 atau 5\% sehingga diperoleh hasil $r_{\text {hitung }}(0,779)>r_{\text {tabel }}(0,524)$ dengan hasil sig 0,000 < a=0,05 yang menunjukkan bahwa terdapat hubungan yang kuat dengan tingkat koefisinsi sebesar 0,779 sehingga $\mathrm{H}_{\mathrm{o}}$ ditolak dan $\mathrm{H}_{\mathrm{a}}$ diterima yang berarti terdapat hubungan antara pendidikan kedisiplinan ibu dengan kebersihan toilet anak usia 4-6 tahun di PAUD Nurul Qomar Kelurahan Mulia Agung Kecamatan Banyuasin III.

Untuk mengetahui hubungan pendidikan kedisiplinan ibu dengan kebersihan toilet anak usia 4-6 tahun di PAUD Nurul Qomar Kelurahan Mulia Agung Kecamatan Banyuasin III dilakukan dengan uji korelasi product moment dnegan menggunakan aplikasi SPSS versi 10 dengan hasil sebagaimana pada gambar 4 . 


\section{Correlations}

\begin{tabular}{|ll|r|r|}
\hline & & Kedisiplinan & Penggunaan Toilet \\
\hline B & Pearson Correlation & 1 & $.799^{* *}$ \\
Kedisiplinan & Sig. (2-tailed) & 15 & .000 \\
& $\mathrm{~N}$ & $.799^{* *}$ & 15 \\
\hline Penggunaan & Pearson Correlation & .000 & 1 \\
Toilet & Sig. (2-tailed) & 15 & 15 \\
& $\mathrm{~N}$ & & \\
\hline
\end{tabular}

**. Correlation is significant at the 0.01 level (2-tailed).

\section{Gambar 4. Hasil Uji Korelasi Product Moment}

Berdasarkan gambar 4 diperoleh hasil uji korelasi product moment dengan taraf signifikasnsi 0,05 atau $5 \%$ sehingga diperoleh hasil $r_{\text {hitung }}(0,779)>r_{\text {tabel }}(0,524)$ dengan hasil sig $0,000<a=0,05$ yang menunjukkan bahwa terdapat hubungan yang kuat dengan tingkat koefisinsi sebesar 0,779 sehingga $\mathrm{H}_{\mathrm{o}}$ ditolak dan $\mathrm{H}_{\mathrm{a}}$ diterima yang berarti terdapat hubungan antara pendidikan kedisiplinan ibu dengan kebersihan toilet anak usia 4-6 tahun di PAUD Nurul Qomar Kelurahan Mulia Agung Kecamatan Banyuasin III.

\section{Pembahasan}

Karakter kedisiplinan merupakan satu karakter yang harus ditanamkan kepada anak usia dini dari 9 karakter menurut Ratna Megawangi karena anak yang disiplin akan memiliki sikap bertanggungjawab sehingga dengan mudah dapat diterima oleh masyarakat. Anak yang disiplin tidak lepas dari cara pendidikan kedisiplinan yang digunakan oleh ibu, dalam menanamkan kedisiplinan pada anak Hurlock berpendapat bahwa terdapat tiga cara untuk menanamkan kedisiplinan anak yaitu: a) disiplind engan cara otoriter; b) disiplind engancara permisif; dan c) disiplin dengan cara demokratis. Hasil penyebaran angket menunjukkan bahwa 40\% ibu di PAUD Nurul Qomar yang memiliki anak berusia 4-6 tahun menggunakan cara kedisiplinan permisif dalam mengajarkan anak menjaga kebersihan toilet, $60 \%$ menggunakan cara otoriter, dan $0 \%$ atau tidak ada yang menggunakan cara demokratis dalam mengajarkan kedisiplinan untuk menjaga kebersihan toilet. Hal ini sejalan dengan pernyataan Hurlock yang mengatakan bahwa pendidikan kedisiplinan dengan cara otoriter lebih umum digunakan oleh masyarakat dan sudah seperti tradisi turun temurun karena dinilai lebih mudah memusatkan perhatian anak terhadap apa yang akan diajarkan. Tanpa disadari bahwa mengajarkan anak pendidikan dengan cara otoriter membuat anak terlihat baik-baik saja namun tersimpan rasa permusuhan di dalam hati anak sehingga saat jauh dari pengawan orang tua anak melakukan hal yang berbeda atau berlawanan dari apa yang telah diajarkan oleh ibunya selama di rumah. Dalam mengajarkan pendidikan kedisiplinan pada anak sering digunakan metode hukuman tetapi lebih baik jika tidak memberikan hukuman untuk memeberikan efek jera tapi memberikan pemahaman agar anak tentang nlai kedisiplinan yang ditanamkan oleh ibu (Aulina, 2013).

Hasil observasi yang dilakukan di PAUD Nurul Qomar diperoleh hasil bahwa terdapat $20 \%$ anak yang tidak buang air kecil pada kloset melainkan di lantai toilet, 46,6\% anak tidak menyiram bekas buang air besar dan buang air kecil, dan 33,3\% anak yang tidak menyiram alat kelamin setelah buang ai kecil dan membersihkan dubur setelah buang air besar. Dari hasil penelitian yang telah dilakukan sejalan dengan penelitian yang dilakukan oleh Magdalena \& Melly (2019) yang menyatakan abhwa terdapat $26 \%$ anak usia prasekolah di Indonesia yang bauang air besar dan buang air kecil di sembarang tempat atau pada kloset yang ada dan di dukung oleh data ari UNICEF yang menunjukkan bahwa hampir 25 juta orang di Indonesia tidak menggunakan toilet saat buang air besar dan buang air kecil di 
sembarang tepat dibandingkan di toilet, karena hal tersebut seperempat dari anak usia dini di Indonesia menderita diare dan penyebab kematian yang besar pada anak di Indonesia (Unicef, 2019). Oleh karena itu lingkungan yang bersih harus dimulai pada diri sendiri untuk disiplin menjaga kebersihan lingkungan karena lingkungan yang bersih membuat hidup menjadi sehat. Untuk menurunkan angka kematian karena diare maka sejak usia dini anak dibiasakan untuk hidup sehat dimulai dengan cara menjaga kebersihan toilet sehingga sangat penting peran orang tua untuk menanamkan kedisiplinan dalam menjaga kebersihan toilet kepada anak sejak usia dini karena anak bisa karena terbiasa dan kebiasaan tersebutlah yang akan dibawanya hingga dewasa.

Kebersihan untuk menjaga toilet anak di sekolah merupakan hasil pembelajaran toilet training yang dilakukan ibu selama di rumah. Toilet training merupakan proses pengajaran kepada anak dalam mengontrol keinginan untuk buang air besar dan buang air kecil secara benar (Rahmah \& Zuhriyah, 2020). Beberapa ahli berpendapat bahwa waktu yang tepat untuk mengajarkan toilet training kepada anak ialah pada usia 24 bulan - 3 tahun karena pada usia tersebut anak mulai mengerti saat diajak untuk berkomunikasi. Tujuan perlunya diajarakannya toilet training sejak usia dinin agar anak terbiasa untuk buang air besar dan buang air kecil di toilet dan mengerti pentingnya menjaga kebersihan diri dan lingkungan. Toilet training dikatakan berhasil jika anak dapat mengungkapkan keinginannya untuk buang air besar dan buang air kecil, anak dapat menahan keinginannya untuk buang air besar dan buang air kecil, dan anak tidak mengompol dicelana (Lutviah, 2017). Keberhasilan toilet training tidak lepas dari pola asuh yang digunakan oleh ibu selama mengajarkan anak untuk menggunakan toilet. Pola asuh merupakan sikap orang tua dalam membina, mendidik, membimbing, dan berinteraksi dengan anaknya dalam kehidupan sehari-hari dengan harapan anak tidak mengalami kesulitan yang berarti dalam hidupnya (Sunarti \& Purwani, 2016).

Berdasarkan hasil penelitian yang telah dilakukan dengan menggunakan uji korelasi product moment diperoleh hasil bahwa $\mathrm{r}_{\text {hitung }}(0,779)>\mathrm{r}_{\text {tabel }}(0,524)$ dengan hasil sig $0,000<$ $a=0,05$ dengan hasil $r_{\text {hitung }}=0,779$ sehingga dapat disimpulkan bahwa terdapat hubungan yang kuat antara pendidikan kedisiplinan ibu dengan keebrsihan toilet anak usia 4-6 tahun di PAUD Nurul Qomar Kelurahan Mulia Agung Kecamatan Banyuasin III. dari hasil epenelitian ini diharapkan tidak hanya orang tetapi guru juga harus membantu meningkatkan kedisiplinan pada anak dalam menjaga kebersihkan toilet karena anak masih diperlukan diperhatikan dan diarahkan agar dapat menjaga kebersihan toilet selama di sekolah seperti memberikan contoh, mengingatkan anak saat anak hendak ke toilet, melalui kegiatan bercerita (Rochimi \& Suismanto, 2019)

\section{SIMPULAN}

Pendidikan kedisiplinan dengan cara permisif ataupun otoriter tidak berhasil baik dalam menanamkan kedisiplinan dengan menjaga kebersihan toilet pada anak usia 4-6 tahun di PAUD Nurul Qomar Kelurahan Mulia Agung Kabupaten Banyausin III karena kedua cara tersebut belum dapat membuat anak menjadi disiplin dalam menjaga kebersihan toilet karena masih terdapat anak yang buang ai kecil di lantai toilet, anak tidak menyriam bekas buang air besar dan buang air kecil, dan anak yang tidak menyriam bekas buang air kecil dan membutuhkan bantuan untuk membasuhkan duburnya setelah buang air besar.

\section{UCAPAN TERIMA KASIH}

Terima kasih banyak kepada ibu kepala sekolah dan para guru di PAUD Nurul Qomar Kelurahan Mulia Agung atas kerjasamanya sehingga penelitian berjalan dengan baik dan lancar sesuai dengan yang diharapkan. Terima kasih saya ucapakan kepada dosen pembimbing 1 sekaligus ketua jurusan Pendidikan Islam Anak Usia Dini UIN Raden Fatah Palembang dan kepada dosen pembimbing 2 sekaligus sekretaris sebagai jurusan Pendidikan Islam Anak Usia Dini UIN Raden Fatah Palembang, dan seluruh ibu dan peserta didik di 
PAUD Nurul Qomar yang telah bersedia untuk menjadi responden pada penelitian ini semoga waktu yang digunakan untuk membimbing menjadi amal baik dan pahala.

\section{DAFTAR PUSTAKA}

Aulina, C. N. (2013). Penanaman Disiplin Pada Anak Usia Dini. PEDAGOGIA: Jurnal Pendidikan, 2(1), 36. https://doi.org/10.21070/pedagogia.v2i1.45

Haryati, S. (2013). Pendidikan Karakter dalam Kurikulum 2013. Pendidikan Karakter Dalam Kurikulum 2013, 19(2), 259-268.

Hayati, D. (2019). Proses Penerapan Etika Bertoilet pada Anak Usia Dini. Jurnal Obsesi : Jurnal Pendidikan Anak Usia Dini, 4(1), 326. https:// doi.org/10.31004/obsesi.v4i1.334

Hurlock, E. B. (1987). Hurlock,Elizabeth.1997. Psikologi Perkembangan Suatu Pendekatan Sepanjang Rentang Kehidupan. Jakarta: Penerbit Erlangga. erlangga.

Hurlock, E. B. (1999). Hurlock, E.B. 1999. Chlid Development Jilid II, terjemahan , Jakarta: Erlangga (Tjandrasa (ed.); II). Erlangga.

Ismail, F. (2018). Statistika Untuk Penelitian Pendidikan dan Ilmu-Sosial. Prenadamedia Group.

Kemenkes RI. (2006). Keputusan Menteri Kesehatan Republik Indonesia Nomor 1429/MENKES/SK/XII/2006 Pedoman Penyelenggaraan Kesehatan Lingkungan Sekolah. In Menteri Kesehatan Republik Indonesia (p. 13). https://peraturan.bkpm.go.id/jdih/userfiles/batang/KEPMENKES_1429_2006.pdf

Lutviah. (2017). Hubungan perilaku orang tua terhadap kemampuan toilet training pada anak usia toddler (18-36 bulan). Stikes Jpg.Ac.Id, 118. http://repo.stikesicmejbg.ac.id/215/1/Skripsi Lutviyah Perpus.pdf

Magdalena, M., \& Melly, M. (2019). Relationship of Parent's Knowledge About Toilet Training with the Ability of 1 - 5 Years Agency in Conducting Toilet Training in the Ibnu Sina Kids, Pekanbaru City. Jurnal Proteksi Kesehatan, 8(2), 35-43. https://doi.org/10.36929/jpk.v8i2.163

Maskuri. (2018). Pendidikan Karakter Disiplin Di Lingkungan Sekolah. Jurnal Tawadhu, 2(1), 340363.

Permendikbud. (2014). Standar Nasional Penilian PAUD Nomor 137 tahun 2014. Menteri Kesehatan Republik Indonesia Peraturan Menteri Kesehatan Republik Indonesia, Nomor 65(879), 2004-2006.

Pramono, D., \& Risnawati, A. (2018). Meningkatkan Kedisiplinan Anak Usia Dini Melalui Latihan Pembiasaan Penggunaan Toilet di KB Al-Hidayah Insan Mandiri Kabupaten Bandung. 2, 61-66. https://doi.org/10.31004/obsesi.v2i1.8

Rochimi, I. F., \& Suismanto, S. (2019). Upaya Guru Menanamkan Nilai-nilai Kedisplinan pada Anak Usia Dini. Golden Age: Jurnal Ilmiah Tumbuh Kembang Anak Usia Dini, 3(4), 231246. https://doi.org/10.14421/iga.2018.34-02

Rohmah, L., \& Zuhriyah, L. (2020). Pelaksanaan Toilet Training Dalam Prespektif Islam Di Ra Al Furqon 2 Kedungwaru Tulungagung. Gender Equality: International Journal of Child and Gender Studies, 6(1), 95. https://doi.org/10.22373/equality.v6i1.6543

Sodik. (2015). Dasar Metodelogi Penelitian. Lieterasi Media Publishing.

Sujiono, Y. N. (2012). Konsep Dasar Pendidikan Anak Usia Dini (P. Indeks (ed.)).

Sunarti, E., \& Purwani, R. (2016). Ajarkan anak keterampilan hidup sejak dini: gunakan setiap kesempatan optimalkan potensi anak. Zikrul Hakim Bestari.

Unicef. (2019). Air, Sanitasi dan Kebersihan (WASH) Mewujudkan lingkungan yang bersih untuk hidup, bermain, dan belajar bagi anak-anak. Unicef.Org. https://www.unicef.org/indonesia/id/air-sanitasi-dan-kebersihan-wash

Yuliana, K. S., Suniyadewi, N. W., \& Udayana., I. M. (2018). Hubungan Pola Asuh Ibu Dengan Keberhasilan Toilet Training Pada Anak Usia Prasekolah Di Posyandu Balita Banjar Intaran Wilayah Kerja UPT Kesmas Tampaksiring II. 5(2), 231-241. https:// doi.org/10.36376/ bmj.v5i2.38

Zaim Elmubarok. (2009). Membumikan Pendidikan Nilai Mengumpulkan yang Terserak, MenyambungYang Terputus dan Menyatukan Yang tercerai. alfabeta. 